\begin{tabular}{|c|c|c|}
\hline$\bigcup_{\text {Universitas }}$ & $\begin{array}{l}\text { OPTIMUM: Jurnal Ekonomi dan Pembangunan } \\
\text { VOL 11, No. } 1,1-11\end{array}$ & $=$ \\
\hline Ahmad Dahlan & https://dx.doi.org/10.12928/optimum.v10i2.15012 & $\frac{e}{\sqrt{6}}$ \\
\hline
\end{tabular}

\title{
The Impact of International Tourism on Economic Growth and Carbon Dioxide Emission in Asean Five Country
}

\author{
Aulia Hapsari Juwita1,a*; Suryanto2,a; Bhimo Rizky Samudro ${ }^{3, a}$ \\ ${ }^{1}$ auliahapsarijuwita@gmail.com; ${ }^{2}$ suryanto@yahoo.com; ${ }^{3}$ bhimosamudr@gmail.com \\ a Faculty of Economics and Business, Sebelas Maret University \\ * corresponding author
}

\section{ARTICLE INFO}

Article history

Received 2021-01-13

Revised 2021-02-16

Accepted 2021-02-25

Keywords

International Tourism

Panel Data

Cointegration Test

Economic Growth

\section{ABSTRACT}

The purpose of this paper is the international tourism have impact on economic growth and carbon dioxide $\left(\mathrm{CO}_{2}\right)$ emissionsin ASEAN Five (Indonesia, Malaysia, Philippines, Thailand, Singapore) or not. There are increase in tourism receipts, GDP, and FDI as well as $\mathrm{CO}_{2}$ emissions approximately $9 \%, 5 \%, 4 \%$ and $26 \%$ respectively. They are always increasing, but is there any relation between international tourism, GDP and carbon dioxide $\left(\mathrm{CO}_{2}\right)$. This research employs data from 1995 to 2018 to examine long-run equilibrium relationships between tourism, $\mathrm{CO}_{2}$, economic growth and foreign direct investment (FDI). Panel analysis with unit root and cointegration test approachis utilized. This paper found that there is a long-term equilibrium relationships between each variable.The tourism receipt, FDI and $\mathrm{CO}_{2}$ emissions affect economic growth positively and statistically significant. In addition, economic growth affect $\mathrm{CO}_{2}$ emissions while tourism does not affect $\mathrm{CO}_{2}$ and FDI indicates a negative relationship on $\mathrm{CO}_{2}$ emissions. Finally, the paper reveals that international tourism receipt affect economic growth but does not affect $\mathrm{CO}_{2}$.

This is an open access article under the CC-BY-SA license.

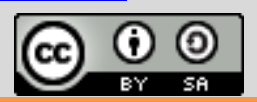

\section{Introduction}

The growth of the tourism sector impacts employment, foreign exchange earnings, infrastructure facilities expansion, capital investment, socio-economic growth, and increased contribution to GDP, and so on, Dayananda and Leelavathi (2016). With a tropical climate, ASEAN has the opportunity to protect the wealth of natural resources that are abundant in the oceans and land. ASEAN is also known as a Southeast Asian country with various cultures, ancestral heritage, and traditional beliefs that are still being lived up to today. The part that can be obtained is used to attract tourists to take a vacation trip to Southeast Asia. 
Global Destination Cities Index: MasterCard 2015 reported that Bangkok, Singapore, and Kuala Lumpur became the world's top 20 destinations based on the Overnight Visitor Arrival Expenditure per City Resident in 2015. Bangkok, the capital of Thailand, reached $\$ 1,072$, Singapore, the capital of Singapore, reached $\$ 2,639$, and Kuala Lumpur, as the capital city of Malaysia, is $\$ 1,933$. Besides, these three cities are also the ten best destinations in Asia / Pacific. The growth of foreign tourists is faster and more constant than the growth in real-world GDP. The existence of a significant tourism demand can stimulate the local economy as a domestic economy. Especially by providing services through goods and services and travel using air transportation can provide high business opportunities.

ASEAN formed the ASEAN Tourism Forum (ATF) to promote member-owned tourism, strengthen cooperation between the tourism industry, and as a forum for exchanging ideas to build the tourism industry together. ASEAN also established the ASEAN Sustainable Tourism Awards (ASTA) program. Award for the best rural and urban tourism products in ASEAN whose benefits are for their purposes. ASTA is a promotional medium to introduce regional tourism, small cities, districts, and villages. This objective serves to ensure the social, cultural, and environmental sustainability of tourism. This information has a relationship with economic growth and tourism development because tourism is part of the sector used to increase economic growth, employment opportunities, and sources of income. Indonesia has also contributed to increasing the tourism sector to increase its foreign tourism exchange by accelerating infrastructure projects and adding transportation to facilitate access to locations.

Tourism is one of the contributors to local revenue that can help develop a region or country. Not only have a positive effect, based on observations, tourism can also harm the environment. Based on observations, the impact of this environment can be in increased air pollution, $\mathrm{CO}_{2}$ emissions, or other environments that cause deterioration, floods, landslides, and blockage of waterways cause inundation and disease. Borhan et al. (2012) explained that pollution alone could reduce human capital, labor productivity, and productivity. Paramitha (2016) stated that it is related to $\mathrm{CO}_{2} . \mathrm{CO}_{2}$ requires energy directly like fossil fuels or indirectly from electricity generated from coal, natural gas, or oil. Tourism is estimated to account for $5 \%$ of global $\mathrm{CO}_{2}$ emissions, and the UNWTO is warning each country to move towards a genuinely green tourism economy where economic growth is wholly separated from environmental or cultural degradation. In ASEAN itself, the relationship between $\mathrm{CO}_{2}$ and economic growth is related to the Kuznets environmental curve. 


\section{Previous Research}

\section{Tourism, Economic Growth, and $\mathrm{CO}_{2}$}

Damanik and Weber (2006) consider tourism as an activity carried out in a different location from residence to release routine activities or simply look for a new atmosphere that is different from the activities every day. Pendit (2002) explained that tourism could immediately boost a country's economic progress by developing and improving transportation and roads. Not only directly encouraging the economy, but also by providing cleanliness programs and facilities for cultural facilities and environmental preservation can also provide satisfaction to tourists. Paramati et al. (2016) used econometric panel techniques to emphasize that tourism has a significant positive impact on economic growth in developed and developing countries. Schubert (2011) added that the increasing demand for tourism causes a dynamic transition of increased economic growth and as a cause of increasing trade conditions.

\section{Tourism on CO2 emissions}

Gössling et al. (2005) estimated that an increase in CO2 emissions for Finland, the United States, Canada, and Australia / New Zealand resulted from tourism activities. Jatuporn and Chien (2011) utilized several foreign tourists' variables, energy consumption, and $\mathrm{CO}_{2}$ emissions from transportation and all economic sectors. The research model was multivariate vector autoregressive (VAR) and unit root diagnosis, causality, and variance decomposition estimates analyzed to show long-run relationships and mass effects. The results indicate a causal relationship between tourism development and $\mathrm{CO}_{2}$ emissions in Thailand during 1986-2010. The causal relationship between tourism development and $\mathrm{CO}_{2}$ emissions also occured in Indonesia. This is due to the consumption of energy through transportation and the economy. This statement was rejected by Scott et al. (2010). The research reported that the tourism sector could become the main actor as a global source of greenhouse gases in the future. The research also offered policy changes and hope that air transportation can reduce $\mathrm{CO}_{2}$ emissions. Sustainable tourism, Weaver (2011) introduces low-carbon economy tourists, limiting the number of flights can be used as a new policy to keep $\mathrm{CO}_{2}$ under control and decrease.

Hypothesis 1, increasing tourism revenue in ASEAN-5 affects economic growth and $\mathrm{CO}_{2}$ emissions.

\section{Economic Growth, Emisi CO2}

A study by Alam (2014) utilized the environmental curve Kuznets hypothesis to investigate changes in the economic structure and trends in carbon dioxide $\left(\mathrm{CO}_{2}\right)$ emissions 
with GDP per capita in Bangladesh. The research also examined the relationship between economic growth and $\mathrm{CO}_{2}$. The results showed that the increasing $\mathrm{CO}_{2}$ resulted in a decrease in growth. Structural changes are needed to assess the increase in economic growth, such as environmental awareness and policies, global cooperation, without which growth will lead to a downward trend. This statement is supported by Panayotou (1993). Research by Peng et al. (2015) supported this relationship, which states that there is a unidirectional causality between GDP and CO2 emissions. Chandran and Tang (2013), using multivariate cointegration and granger causality, give results if economic growth plays a more significant role in contributing to $\mathrm{CO} 2$ emissions in ASEAN.

Hypothesis 2, increasing economic growth affects increasing $\mathrm{CO} 2$ emissions.

\section{FDI, Economic Growth and $\mathrm{CO}_{2}$ Emission}

Empirical research by Alfaro et al. (2004) utilized cross-country data from 1975-1995. The result showed that FDI played an essential role in contributing to economic growth. In developing countries, financial markets are well-developed, and the FDI affects economic growth significantly. Roy and Van den Berg (2006) examined the relationship between FDI and economic growth with time-series data entered into a simultaneous equation model (SEM). The results explicitly captured the bi-directional relationship between FDI and economic growth in the U.S. The results revealed a significant, positive, and economically meaningful impact on US growth. However, the SEM results also show uncertainty around the relationship between economic growth and FDI in general. This is due to the scarcity of long-run data while multinational companies have expanded their networks to world markets. Thus, some new researchers need to add explanatory variables to overcome these difficulties.

A study by Chandran and Tang (2013) used multivariate cointegration and Granger causality. That research stated that there is no relationship between FDI and $\mathrm{CO}_{2}$ in ASEAN, but the results found a short-term causality relationship between FDI and $\mathrm{CO}_{2}$ in the Philippines and Singapore. Merican et al. (2017) added that there was a significant relationship to pollution. The research was conducted using Autoregressive Distributive Lag (ARDL). Based on the results, FDI increases pollution in Malaysia, Thailand, and the Philippines but excludes Indonesia, where FDI is inversely related to pollution and Singapore is insignificant or has no effect.

Hypothesis 3, an increase in FDI affects economic growth, but an increase in FDI does not necessarily show an effect and increase $\mathrm{CO} 2$ emissions. 


\section{Cointegration}

Cointegration is employed to determine whether there is a long-run relationship between variables. Cointegration is needed to be done in time-series data to determine whether the data is stationary or not. If the data is stationary, it indicates that the variables are integrated or have a long-run relationship. Hatzigeorgiou et al. (2011) employed multivariate cointegration and Greek causality analysis, 1977-2007. The result emphasized the existence of a long-run relationship to economic growth, $\mathrm{CO}_{2}$ emissions, and energy consumption. Chandran and Tang (2013) used multivariate cointegration and Granger causality analysis, emphasizing that FDI and CO2 emissions have a long-run causal relationship. Lee and Brahmasrene (2013) added a long-run relationship between economic growth, $\mathrm{CO} 2$, tourism, and FDI with the cointegration panel.

Hypothesis 4, There is a long-run relationship between economic growth, $\mathrm{CO}_{2}$, tourism, and FDI.

\section{Data And Method}

This study is quantitative research. This research utilizes secondary data from 1995 to 2018 with five countries as the pioneers of the establishment of ASEAN, namely Indonesia, Malaysia, Philippines, Thailand, and Singapore.

Normalization and transformation: Normalization of data is needed because there are different units in one of the variables to be processed. $\mathrm{CO}_{2}$ emissions, which are units of metric tons, must first be converted into US \$ units of measurement to be the same as other variables. Thus the log transformation is required to reduce the possibility of dynamic distortion from the serial nature. Log transformation was also carried out in order to get better results.

Correlation: Table 1 is the result of the Pearson panel series correlation. Correlation is done to see how closely the relationship between variables is. The correlations between the variables GDP, $\mathrm{CO}_{2}$, Tourism, and FDI are all significant. GDP is positively related to $\mathrm{CO} 2$, Tourism, and FDI. The GDP correlation to $\mathrm{CO} 2$ is very strong (p-value> $0.5-0.75$ ). $\mathrm{CO}_{2}$ is positively correlated with tourism. However, FDI has a negative correlation.

\section{Unit Root Test}

The unit root test is employed to determine the data stationarity. Before running the unit root test panel data, it must consider asymptotic action on time series in $\mathrm{T}$ dimension and cross-sectional in $\mathrm{N}$ dimension. Average data must be constant, independent of time and variance of fluctuation. Four types of unit root tests can be employed to determine stationarity in the panel data, Levin-Lin-Chu (LLC); Breitung; I'm-Pesar-Shin (IPS); Fisher, 
ADF; and Fisher, PP.

\section{Panel Cointegration Test}

Maddala and $\mathrm{Wu}$ (1999) in Lee and Brahmasrene (2013) explained that the fisher-type panel cointegration test using the Johansen (1991) test is more efficient than EngleeGranger. This is because there is a significant and broad maximum likelihood. The Johansen procedure for testing the cointegration relationship has a small sample of only the trace test and the maximum eigenvalue test. The two samples can be used simultaneously.

\section{Table 1. Correlation Pearson Test}

\begin{tabular}{lcccc}
\hline & GDP & CO $_{2}$ & $\begin{array}{c}\text { Tourism } \\
\text { Revenue }\end{array}$ & FDI \\
\hline GDP & 1 & & & \\
CO & & 1 & & \\
Tourism & 0.63734 & 0.38115 & 1 & \\
Revenue & 0.58792 & -0.33205 & 0.39298 & 1 \\
FDI & 0.31097 & &
\end{tabular}

P-value $>0.05$, Sarwono (2006)

\section{Panel Data Regression Test}

This study tested the panel data regression model by combining time-series and crosssection data sets. The data estimation used is the Fixed Effect Model (FEM) by doing the Hausman Test first. The addition of dummy variables is emphasized on the Fixed Effect Model panel regression parameters. Thus the method is often called the Least Square Dummy Variable Model. The panel data regression model is as follows:

$$
\begin{aligned}
& G D P_{i t}=\alpha_{0}+\alpha_{1} C O_{2 i t}+\alpha_{2} T R S_{i t}+\alpha_{3} F D I_{i t}+v_{i t} \\
& \text { and } \\
& C O_{2 i t}=\alpha_{0}+\alpha_{1} G D P_{i t}+\alpha_{2} T R S_{i t}+\alpha_{3} F D I_{i t}+v_{i t}
\end{aligned}
$$

Notation:

$$
\begin{array}{ll}
\alpha & =\text { Parameter (Constanta and efficient) } \\
\mathrm{GDP} & =\text { Economic Growth } \\
\mathrm{CO}_{2} & =\text { Carbon dioxide emission } \\
\mathrm{TRS} & =\text { Tourism Revenue } \\
\mathrm{FDI} & =\text { Foreign Direct Investment } \\
i & =\text { ASEAN } 5 \\
t & =\text { Year from } 1995 \text { to } 2018
\end{array}
$$




\section{Result and Discussion}

This chapter focuses on the results. Table 2 results from the unit root test using either Levin; Breitung; I'm-pesar-shin; fisher, ADF; and Fisher, PP. The results obtained from the unit root test at the 1 st difference are that each variable does not contain a unit root test. In other words, the data is stationary. It is proven by the probability of the 1st difference for each variable $<0.01$. Overall the assumption results were obtained from the unit root test at normal asymptotics.

Table 2. Unit Root Test

\begin{tabular}{|c|c|c|c|c|c|c|c|}
\hline \multirow{2}{*}{$\begin{array}{l}\text { Variable } \\
\text { Method }\end{array}$} & GDP & $\mathrm{PP}$ & $\mathrm{CO}_{2}$ & \multicolumn{2}{|c|}{$\begin{array}{l}\text { Tourism } \\
\text { Revenue }\end{array}$} & \multicolumn{2}{|c|}{ FDI } \\
\hline & Level* & Level* & $\begin{array}{c}\text { 1st } \\
\text { diff** }\end{array}$ & Level* & 1st diff & Level* & 1st diff** \\
\hline Levin & 1.80917 & $-3.47041-1.35761$ & -4.74144 & -0.97495 & -5.26793 & -0.00165 & -2.7548 \\
\hline Breitung & 0.99639 & -2.368790 .72382 & -2.88923 & 2.06950 & -0.54114 & 2.54039 & -0.22546 \\
\hline $\begin{array}{l}\text { Im, } \\
\text { Pesaran, } \\
\text { shin }\end{array}$ & -1.17375 & $-0.70765-0.39126$ & -4.29170 & 0.60991 & -3.56921 & -0.49156 & -5.39386 \\
\hline $\begin{array}{l}\text { Fisher- } \\
\text { ADF }\end{array}$ & 14.0208 & 10.873414 .3968 & 35.4591 & 6.51055 & 32.0415 & 15.7768 & 48.4368 \\
\hline $\begin{array}{l}\text { Fisher- } \\
\text { PP }\end{array}$ & 5.36055 & 24.542313 .2332 & 53.7989 & 4.77645 & 53.7886 & 23.0455 & 334.885 \\
\hline
\end{tabular}

${ }^{*}$ p-value $>0.01,{ }^{* *}$ p-value $<0.01$, asymptotic normality.

Table 3 showed Panel Johansen cointegration result. Probability value of H0 rejection from cointegration did not utilized at $>0.01$. There is a probability if variables are cointegrated individually but not linear Based on Johansen cointegration Fisher type. Based on the results of the Johansen cointegration test on the fisher type, there is a possibility that the variables cointegrate individually but there is no linear trend individually in the autoregressive vector model. The probability value $<0.01$ indicates that these variables are cointegrated, meaning they have a long-term relationship in the hypothesis "none" and "most 1".

Table 3. Fisher Type Johansen Panel Cointegration Test

\begin{tabular}{lcc} 
Regression Model & GDP = f (CO2, Tourism Revenue, FDI) \\
\hline Hypothesis No. of CE(s) & Trace Stat. & Eigen Stat. \\
\hline None & $52.83^{*}$ & $28.46^{*}$ \\
\hline At most 1 & $30.57^{*}$ & $21.80^{*}$ \\
\hline At most 2 & 17.14 & 14.52 \\
\hline At most 3 & 16.32 & 16.32 \\
\hline *p-value < 0.01 & & \\
\hline P-value MacKinnon-Haug-Michelis (1999) & & \\
\hline
\end{tabular}


The cointegration results indicate that these variables have a long-run relationship. The results obtained support the fifth hypothesis. The fifth hypothesis stated a long-run relationship between tourism receipts, GDP, $\mathrm{CO}_{2}$ emissions, and FDI.

Hausman-test is performed to compare and differentiate fixed effect and random effect models. The Housman test uses the chi-square value. Thus, the decision to choose the panel data method can be determined statistically. The results showed that both models, namely GDP (Chi-square $=38,740$ ) and $\mathrm{CO}_{2}$ emissions (Chi-square statistic $=46,886$ ) each have a probability value of $0.000<0.05$. Thus, $\mathrm{H} 1$ is accepted, which means that the fixed effect is preferable.

Table 4. Fixed-Effect Panel Analysis

\begin{tabular}{lcccc}
\hline Variable & \multicolumn{2}{c}{$\begin{array}{c}\text { GDP }=\text { f (Em. CO2, Tourism } \\
\text { Revenue, FDI) }\end{array}$} & $\begin{array}{c}\text { CO2 }=\text { f (Em.GDP, Tourism } \\
\text { Revenue, FDI) }\end{array}$ \\
\cline { 2 - 5 } & Coeff & Prob & Coeff & Prob \\
\hline C02 & 0.666112 & 0.000 & & 0.0000 \\
\hline GDP & & & 0.372561 & 0.2904 \\
\hline Tourism Revenue & 0.541343 & 0.000 & 0.070820 & 0.0010 \\
\hline FDI & $1.20 \mathrm{E}-11$ & 0.000 & $-7.03 \mathrm{E}-12$ & 0.5698 \\
\hline Constanta & 5.635382 & 0.000 & 0.603280 & 0.960099 \\
\hline R-Squad & \multicolumn{2}{c}{0.888447} & \multicolumn{2}{c}{316.2460} \\
\hline F-statistic & 104.6740 &
\end{tabular}

Table 4 menjelaskan hasil yang diperoleh dari analisis panel dengan model fixed effect. Model yang tertuliskan sebagai berikut:

$$
\begin{gathered}
G D P=5.635382+0.666112 \alpha_{1 i t}+0.541343 \alpha_{2 i t}+1.20 E-11 \alpha_{3 i t}+v_{i t} \\
\text { and } \\
C O_{2}=0.603280+0.372561 \alpha_{1 i t}+0.070820 \alpha_{2 i t}-7.03 E-12 \alpha_{3 i t}+v_{i t}
\end{gathered}
$$

Hypothesis 1: The results showed that tourism affects economic growth, but it does not affect $\mathrm{CO}_{2}$ emissions. An increase of $1 \%$ in tourism revenue indicates a $54 \%$ increase in economic growth but not $\mathrm{CO} 2$ emissions. The positive effect of tourism revenue on economic growth is that every $1 \%$ increase in tourism revenue will increase by $60 \%$.

These research results are in line with the previous research that tourism stimulates overall economic growth. Tourism can contribute to the progress of ASEAN countries in reducing poverty. Tourism also provides jobs, increases income, and supports economic, social, cultural, and educational.

This study does not show any relationship between tourism revenues and $\mathrm{CO}_{2}$ emissions. The results showed contradiction from previous research. It showed that an increase in tourism revenue does not always impact the environmental damage, which increases $\mathrm{CO}_{2}$ emissions. 
Hypothesis 2: The results showed that the economic growth in these five countries strongly influences $\mathrm{CO}_{2}$. If there is a $1 \%$ increase in economic growth, there will be a $37 \%$ increase in $\mathrm{CO}_{2}$ emissions. Behind the increase in economic growth from an increase in tourism revenue, a $1 \%$ increase in economic growth led to an increase in $\mathrm{CO}_{2}$ emissions by $37 \%$. These results prove that economic growth stimulates an increase in $\mathrm{CO}_{2}$ emissions. Economic growth is associated with increasing $\mathrm{CO}_{2}$ emissions, increased production due to high levels of human consumption, and low human awareness of the environment. Illegal deforestation makes trees emit 02 to the maximum. Waste disposal and infrastructure development that is still low on environmentally friendly power can increase $\mathrm{CO}_{2}$ emissions.

Hypothesis 3: The results show that FDI in ASEAN 5 countries positively affects economic growth but harms $\mathrm{CO}_{2}$. A $1 \%$ increase in FDI will increase economic growth by $1.20 \mathrm{E}-9 \%$ and decrease $\mathrm{CO}_{2}$ emissions by $7.03 \mathrm{E}-10 \%$. 1\% increase in FDI will increase economic growth by $1.20 \mathrm{E}-9 \%$ and reduce $\mathrm{CO}_{2}$ emissions by $7.03 \mathrm{E}-10 \%$. FDI through foreign capital can contribute to increasing the economic growth of a country. ASEAN also places investment as the main factor used in the ASEAN economy.

\section{Conclussion And Suggestion}

This study revealed a long-run equilibrium relationship between tourism, $\mathrm{CO}_{2}$ emission, economic growth, and Foreign Direct Investment (FDI). The results showed that tourism, FDI, and $\mathrm{CO}_{2}$ affect economic growth positively significant. Economic growth showed a positive impact on $\mathrm{CO}_{2}$ emission while tourism does not affect $\mathrm{CO}_{2}$. Furthermore, FDI showed that there is a negative impact on $\mathrm{CO}_{2}$ emission.

This study will assist policymakers always to pay attention to the environment, especially air pollution, and make environmentally friendly policies to increase economic growth. Based on the results, the researcher also represents new findings if there is no link between international tourism revenues and $\mathrm{CO}_{2}$ emissions.

\section{REFERENCES}

Alam, Janifar. 2014. On the relationship between economic growth and $\mathrm{CO}_{2}$ Emissions: The Bangladesh Experience. IOSR Journal of Economics and Finance, 5 (6)(1), 36-41.

Alfaro, L., Chanda, A., Ozcan, S. K. 2004. FDI and economic growth: role of local financial markets. Journal of International Economics, 64 (1), 89-112

Borhan, H., Ahmed, E. M., Hitam, M. 2012. The Impact of Co2 on economic growth in ASEAN 8. Procedia-Social and Behavioral Sciences, 35, 389-397. 
Chandran, V. G. R., Tang, C. F. (2013). The impact of transport energy consumption, foreign direct investment, and income on $\mathrm{CO}_{2}$ emissions in ASEAN-5 economies. Renewable and Sustainable Energy Reviews, 24, 445-453.

Damanik, J., Weber, H. 2006. Perencanaan Ekowisata Dari Teori ke Aplikasi. Yogyakarta: PUSPAR UGM dan Andi.

Ekanayake, E.M., Long, A. E. 2012. Tourism Development and Economic Growth in Developing Countries. The International Journal of Business and Finance Research, 6 (1), 51-63.

Gössling, Stefan, Paul Peeters, Jean-Paul Ceron, Ghislain Dubois, Trista Patterson, and Robert B. Richardson. 2005. "The Eco-efficiency of Tourism." Ecological Economics, 54 (4): 417-34.

Hatzigeorgiou, E., Polatidis, H., Haralambopoulos, D. 2011. $\mathrm{CO}_{2}$ emissons, GDP and energy intensity: A multivariate cointegration and causality analysis for Greece, 1997-2007. Applied Energy, 88 (4), 1377-1385.

Jatuporn, Chalermpon and Chien, Li-Hsien. 2011. Tourism Development Vs. $\mathrm{CO}_{2}$ emissions in Thailand. The 1st Environment Asia International Conference on "Environmental Supporting in Food and Energy Security: Crisis and Opportunity, 22-25.

Johansen, S. 1991. Estimation and hypothesis testing of cointegration vectors in Gaussian vector autoregressive models. Econometrica, 59, 1551-1580.

Hendrick-Wong, Y., Choong, Desmond. 2015. MasterCard 2015 Global Destination Cities Index, Tracking Global Growth: 2009-2015. MasterCard

Kreishan, F. M. M. 2010. Tourism and Economic Growth: The Case of Jordan, European Journal of Social Sciences, 15 (2), 229-234.

Lee, J. W., Brahmasrene, T. 2013. Investigating the influence of tourism on economic growth and carbon emissions: Evidence from panel analysis of the European Union. Tourism Management, 38, 69-76.

Massidda, C., Mattana, P. 2013. A SVECM Analysis of the Relationship between International Tourist Arrivals, GDP and Trade in Italy. Journal of Travel Research, 52(1), 92-105.

Merican, Y., Yusop, Z., Noor, Z. M., Hook, L. S. 2007. Foreign Direct Investment and the Pollution in Five ASEAN Nations. Int. Journal of Economics and Management, 1 (2), 245-261.

Panayotou T. 1993. Empirical test and policy analysis of environmental degradation at different stages of economic development, WP 238. Technology and Employment Program. International labor office. Geneva 
Paramati, S. R., Alam, Md. S., and Chen, C.F. (2016). The Effects of Tourism on Economic Growth and $\mathrm{Co}_{2}$ emissions: A Comparison between Developed and Developing Economies. Journal of Travel Research, 1-13.

Pendit, Nyoman S. 2002. Ilmu Pariwisata Sebuah Pengantar Perdana. Jakarta: PT. Pradnya Paramita.

Peng, H., Tan., X. Li, Y., Hu, L. 2016. Economic growth, foreign direct investment and CO2 emissions in China: A Panel Granger Causality Analysis. Sustainability Journal, MDPI, 8, 233, 1-13.

Roy, A. G., Van den Berg, H. F. 2006. Foreign Direct Investment and Economic Growth. Global Economy Journal, 6 (1), 1-19.

Schubert, S. F., Brida, J. G. and Risso, W. A. 2011. The impacts of international tourism demand on the economic growth of small economies dependent on tourism. Tourism Management, 32, 377-385.

Scott, D. (2011). Why sustainable tourism must address climate change. Journal of Sustainable Tourism, 19(1), 17-34

Scott, D., Peeters, P., \& Gössling, S. (2010). Can tourism deliver its "aspirational” greenhouse gas emissions reduction targets? Journal of Sustainable Tourism, 18(3), 393-408.

Weaver, D. (2011). Can sustainable tourism survive climate change? Journal of Sustainable Tourism, 19(1), 5-15 